\title{
Gypsum amendment of soils reduces phosphorus losses in an agricultural catchment
}

\author{
Petri Ekholm*1, Pasi Valkama², Elina Jaakkola ${ }^{1}$, Mikko Kiirikki ${ }^{3}$, Kirsti Lahti ${ }^{2}$ and Liisa Pietola ${ }^{4}$ \\ ${ }^{1}$ Finnish Environment Institute, PL 140, FI-00251 Helsinki, Finland \\ ${ }^{2}$ The Water Protection Association of the River Vantaa and Helsinki Region, Asemapäällikönkatu 12 B, FI-00520 Helsinki \\ ${ }^{3}$ Luode Consulting Oy, Olarinluoma 15 B, FI-02200 Espoo, Finland \\ ${ }^{4}$ Yara International ASA, Yara Suomi Oy, Mechelininkatu 1a, P.O.Box 900, Fl-00181 Helsinki, \\ Finland (Current address: Central Union of Agricultural Producers and Forest Owners, PL 510, FI-00101 Helsinki, Finland) \\ *e-mail: petri.ekholm@environment.fi
}

\begin{abstract}
We estimated the changes in the losses of particulate and dissolved phosphorus (P) after treating 93 ha of agricultural fields with gypsum $\left(4 \mathrm{tha}^{-1}\right)$ in a 245 ha catchment in southern Finland. Runoff was monitored using online sensors and manual sampling during one high-flow period before and six periods after the gypsum amendment. Turbidity recorded by the sensors correlated with particulate $\mathrm{P}$ analysed in the laboratory, which enabled the evaluation of changes in particulate $P$ from the online data. Using a covariance model, gypsum amendment was estimated to have reduced the loss of particulate $P$ by $64 \%$. The loss of dissolved reactive $P$ appeared to decrease by one third, but was estimated with less precision. No such changes were found during the same period in a nearby 'reference' catchment, where gypsum was not used. Gypsum did not affect soil test values for $\mathrm{P}, \mathrm{K}, \mathrm{Mg}$ or $\mathrm{Ca}$, but it did increase the ionic strength and soil test $\mathrm{SO}_{4}$. In clayey catchments discharging into the sea, gypsum may provide an efficient means to reduce $\mathrm{P}$ losses from field cultivation. The duration of the gypsum effect and impact of $\mathrm{SO}_{4}$ associated with gypsum amendment on the ecology of rivers and lakes has yet to be determined.
\end{abstract}

Key words: gypsum, phosphorus, agriculture, eutrophication, sulphate, monitoring

\section{Introduction}

Many water bodies in Finland will not achieve the good ecological state demanded by the EU's Water Framework Directive (2000/60/EC) unless nutrient loading from agriculture is drastically reduced (Ministry of the Environment 2009). Erodible sloping fields constitute high-risk sites for losses of $P$ bound to soil particles, but flat fields on dispersive soils may also show considerable particulate P losses (Aura et al. 2006, Withers et al. 2007). Highrisk sites for dissolved $\mathrm{P}$ losses include fields with high soil test $\mathrm{P}$ levels, which have a long history of manure application or cultivation of heavily fertilised high-value crops (Uusitalo et al. 2007).

Agricultural water protection measures targeting particulate or dissolved $\mathrm{P}$ encompass a variety of actions ranging from soil conservation and balanced fertilisation to implementing buffer zones and constructing wetlands. On top of these measures, there are novel techniques that can potentially have an enhanced impact on $\mathrm{P}$ losses from high-risk sites (Turtola et al. 2010). These include the use of soil amendment such as natural materials, industrial (side) products and waste products (e.g. Ballantine and Tanner 2010, Ippolito et al. 2011). Recently, several experiments have been performed with different types of amendments in Finland (e.g. Närvänen et al. 2008, Muukkonen et al. 2009, Lillunen et al. 2011, Kirkkala et al. 2012). Gypsum (CaSO $\cdot 2 \mathrm{H}_{2} \mathrm{O}$ ), while being a natural mineral, is also formed in industrial processes and in flue-gas desulphurisation. Gypsum has been used as a soil amendment for a long time (Shainberg et al. 1989), but its use in controlling P losses is relatively new.

Amending soil with gypsum increases the ionic strength and Ca concentration in the soil solution (Aura et al. 2006, Pietola 2008), which should promote the flocculation of soil particles and thereby reduce erosion. Erosion may be further reduced if the physical condition of the soil is changed so that infiltration increases (Cox et al. 2005). On the other hand, adsorption of $\mathrm{PO}_{4}$ should become stronger due to increasing ionic strength and $\mathrm{Ca}$ (Yli-Halla and Hartikainen 1996) and possibly due to precipitation with Ca (Zhu and Alva 1994). Finally, the solubility of organic P can be decreased, for example due to complexation (Cox et al. 2005, Murphy and Stevens 2010). Thanks to these processes, both particulate and dissolved losses of $\mathrm{P}$ to waters should be lessened.

The effect of gypsum on nutrient transport has been studied mostly under laboratory conditions (Zhu and Alva 1994, Boruvka and Rechcigl 2003, Aura et al. 2006, Favaretto et al. 2006, Pietola 2008, Watts and Torbert 2009, El- 
rashidi et al. 2010, Murphy and Stevens 2010, Uusitalo et al. 2012, Grubb et al. 2011, Kumar and Saha 2011) with only a few examples from catchment scale studies (Cox et al. 2005). For instance, gypsum was shown to reduce $P$ losses from the slightly acidic Finnish soils in incubation-leaching studies (Pietola 2008) and in experiments with soil cores under artificial rainfall (Uusitalo et al. 2012). Gypsum was also found to cut down P losses from a Miami silt loam (Indiana, US) by using a rainfall simulator and erosion pans (Favaretto et al. 2006). Such studies give information on the processes involved, but the results may not be extrapolated to field scale, where numerous pedological and hydrological phenomena coincide with an array of farming practices. Cox et al. (2005) carried out a sub-catchment study in South Australia in a texture-contrast soil with high inputs of superphosphate and cattle grazing all year round. In that study, although the size and stability of structural aggregates increased considerably after the gypsum amendment, the effect on P concentrations was not as marked.

We monitored the effect of gypsum on the losses of particulate and dissolved $\mathrm{P}$ from a catchment in southern Finland. We also monitored concomitant changes in soil chemistry and screened potential side effects of gypsum, placing special emphasis on $\mathrm{SO}_{4}$ losses that may have adverse effects on freshwater ecology (Hasler and Einsele 1948, Caraco et al. 1989, Smolders and Roelofs 1993).

\section{Materials and methods}

\section{Experimental catchment}

The Nummenpää catchment is located in the Nurmijärvi municipality, southern Finland (Fig. 1). It forms a 245-hectare sub-catchment of the Lepsämänjoki, a tributary of the Vantaa discharging into the Gulf of Finland. Gypsum was spread in the catchment in autumn 2008, and here the effects on runoff-P are reported for the first three years as compared with pre-gypsum period and with the situation in a nearby 'reference' catchment where gypsum was not used.

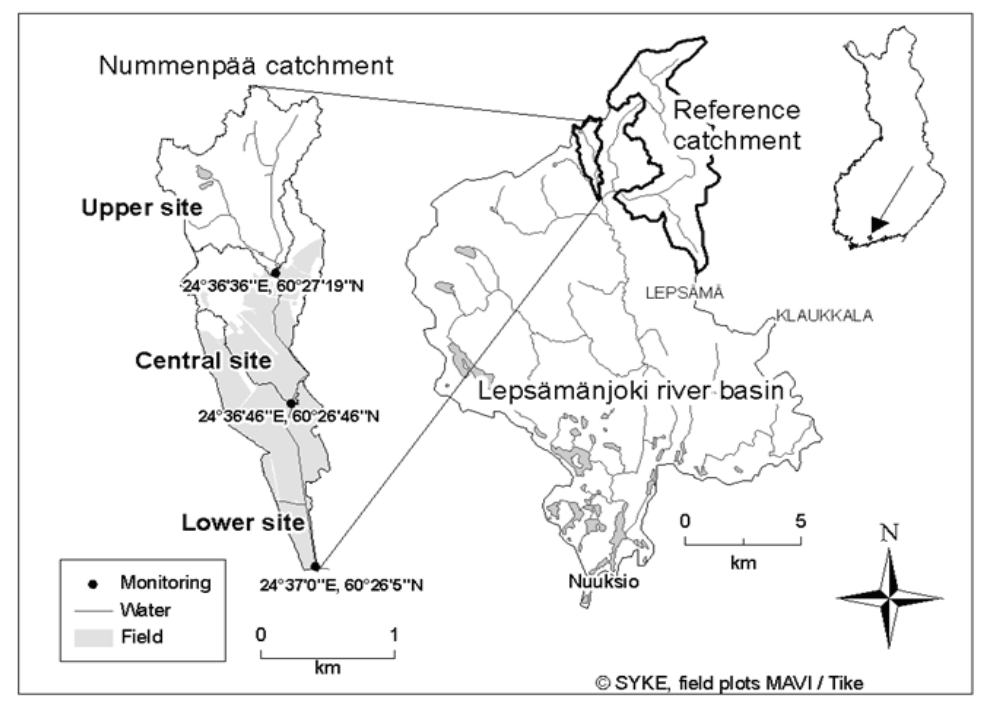

Fig. 1. Locations of the Nummenpää catchment, the monitoring sites therein, and the nearby reference catchment.

The Nummenpää catchment was delineated from a digital elevation model (DEM; National Land Survey of Finland, Licence $7 / \mathrm{MML} / 11$ ) based on LiDAR data, with a minimum vertical resolution of $0.3 \mathrm{~m}$ and a grid cell size of $2 \times 2 \mathrm{~m}$. The catchment can be divided into two parts on the basis of land use and soil texture. The upper part is forested and has rocky areas (Dystric Leptosol) and eskers (Haplic Podzol, Finnish Soil Database 2010, Fig. 1). Some forestry activity has been performed there, but their estimated contribution to the nutrient load is negligible (see 'Source apportionment'). The lower part is cultivated and has clayey soils (Vertic Cambisol). According to soil analyses (see below), the topsoil texture of agricultural fields is mainly silty clay loam but there are also some coarser soils. Of the entire catchment area, fields account for $41 \%$ and forests $44 \%$, with the remaining area being used for purposes such as housing (Table 1). The catchment had 73 inhabitants in 2008 (YKR 2011), with none of 
the houses connected to central sewerage systems but having septic tanks, sometimes followed by an enhanced wastewater treatment (Autio K, personal communication).

Table 1. Characteristics of the Nummenpää catchment (three sites) and the reference catchment.

\begin{tabular}{llrrrrrr}
\hline Catchment & Site & $\begin{array}{r}\text { Area } \\
\text { (ha) }\end{array}$ & $\begin{array}{r}\text { Fields }^{1} \\
(\%)\end{array}$ & $\begin{array}{r}\text { Gypsum spread } \\
\text { (\% of fields) }\end{array}$ & $\begin{array}{r}\text { Forest }^{2} \\
(\%)\end{array}$ & $\begin{array}{r}\text { Other }^{2} \\
\text { (\%) }\end{array}$ & $\begin{array}{r}\text { Inhabitants }^{3} \\
\text { (No) }\end{array}$ \\
\hline Nummenpää & Upper & 97 & 0.3 & 0.0 & 92.4 & 7.3 & 6 \\
& Central & 177 & 22.7 & 90.2 & 60.2 & 17.1 & 62 \\
& Lower & 245 & 41.4 & 91.3 & 44.1 & 14.5 & 73 \\
Reference & & 2370 & 32.8 & 0.0 & 48.2 & 19.0 & 2217 \\
\hline
\end{tabular}

${ }^{1}$ Based on Agency for Rural Affairs (Mavi) statistics (Tike, Decision 008/411/2008)

${ }^{2}$ Based on the CORINE land cover database 2006; "Other" includes e.g. built areas, wetlands and roads

${ }^{3}$ Based on YKR (2011)

The mean slope of the field area was $1.9 \%$ (range $0.6 \%-4.8 \%$ ). According to the Field Drainage Association of Southern Finland and the farmers of the study area, approximately $72 \%$ of the field area had sub-surface drains. However, information on the location, directions and the condition of drainage pipes was not available for all fields. Most of the pipes were installed in the 1950s and 1960s, but some renovation has taken place more recently.

According to the field register owned by the Agency for Rural Affairs, $86 \%$ of the fields were planted with spring cereals in $2008,12 \%$ with cabbage, and $2 \%$ was fallow or uncultivated fields. At the end of the project, the local farmers were interviewed to uncover possible changes in farming practices that might affect $\mathrm{P}$ losses. According to the responses (coverage approximately $86 \%$ of the fields), the proportion of plants in 2008-2011 was as follows: $80 \%$ spring cereals, $5 \%$ winter cereals and $11 \%$ cabbage, the rest left to lie fallow. There was a minor increase in winter cereals over time. In addition, autumn ploughing accounted for $73 \%$ of the field area, reduced tillage $18 \%$ and no-till $6 \%$, with reduced tillage gaining in popularity at the expense of autumn ploughed area. The mean fertilising rates were $34 \mathrm{~kg} \mathrm{ha}^{-1} \mathrm{P}$ and $27 \mathrm{~kg} \mathrm{ha}^{-1} \mathrm{~S}$ for cabbage and $8 \mathrm{~kg} \mathrm{ha}^{-1} \mathrm{P}$ and $11 \mathrm{~kg} \mathrm{ha}^{-1} \mathrm{~S}$ for cereals.

Soil samples were collected based on the guidelines of Viljavuuspalvelu (Soil Analysis Service) to complement the soil quality data owned by the farmers. This data, taken from the plough layer before sowing and fertilising, covered $94 \%$ of the fields altogether. To analyse the effect of gypsum on soil chemistry, composite samples (5 aliquots from a circle with a diameter of $1 \mathrm{~m}$ ) from surface soil $(0-20 \mathrm{~cm})$ were taken with a spade from 17 GPS-defined sites once before and five times after the amendment. The sites were mostly on cabbage fields, since these were ploughed each year and thus changes in tillage practices did not affect the results. The soil analyses involved the extraction of dry soil with a solution of $0.5 \mathrm{M}$ ammonium acetate and $0.5 \mathrm{M}$ acetic acid at $\mathrm{pH} 4.65$ (1:10 by volume, Vuorinen and Mäkitie 1955) followed by determination of $\mathrm{Ca}, \mathrm{Mg}$, $\mathrm{K}$ and $\mathrm{S}$ by using ICP and $\mathrm{P}$ by the molybdenum blue method (Murphy and Riley 1962). Conductivity and pH were measured from a soil-water suspension (1:2.5 by volume). The textural composition of soil was analysed by settling and sieving (Elonen 1971).

In winter 2011, a gas pipe was dug through the catchment (middle of the central and lower site) causing temporary turbidity peaks. As these took place before the flood period, their effect on $\mathrm{P}$ loss was assumed negligible. In addition, the construction works may have broken drainage pipes and thereby affected hydrology.

\section{Gypsum amendment}

Of the 101 hectares of agricultural fields in the catchment, 93 hectares (91.3\%, Table 1) were amended with gypsum ( $4.1 \mathrm{t} \mathrm{ha}^{-1}$ ) after the harvest and before tillage in 2008. Spreaders for moist lime and dry manure were both used and found appropriate for gypsum field spreading (Palva and Alasuutari 2009). The gypsum consisted of phosphogypsum, a by-product from the manufacturing of phosphoric acid by digestion of phosphate ore concentrate with sulphuric acid. The phosphate ore originates from igneous phosphate rock (fluoroapatite) in Siilinjärvi, Finland and is free of $\mathrm{Cd}$ and radioactivity. It contained less than $0.2 \% \mathrm{P}$ and $0.3 \% \mathrm{~F}$, of which $60 \%$ consisted of water-extractable F forms (Reetta Puska of Yara Suomi Oy, personal communication). 


\section{Reference catchment}

The nearby upper reaches of the Lepsämänjoki served as a 'reference' catchment, where no gypsum was used (Fig. 1). This catchment has been monitored with automatic sensors for turbidity and by manual sampling for nutrients and TSS since 2005 (Valkama et al. 2007a). Although larger (2370 ha), the catchment resembles the Nummenpää catchment; that is, it has no lakes, the field percentage is 32.8 , the fields have mostly clayey soils and their mean slope is $1.9 \%$ (range $0.3 \%-8.3 \%$ ). The number of inhabitants not connected to a central sewage system in the reference catchment is close to that in Nummenpää: 0.26 vs. $0.29 \mathrm{ha}^{-1}$, respectively.

\section{Runoff monitoring}

Runoff quality was monitored at three sites representing the upper, central and lower reaches (Fig. 1, Table 1) along the main channel in the Nummenpää catchment from February 2008 to May 2011 - i.e. before, during and after the gypsum amendment. Spring 2008, together with the first week of September 2008, formed the 'non-gypsum period' to which the data collected after gypsum amendment was compared. Automatic online sensors (YSI 600 OMS, YSI Inc), for recording turbidity, conductivity and temperature at one-hour intervals, were deployed at the central and lower site for seven measurement periods of about two months, in spring and autumn. No sampling or measurement was performed in summer or midwinter, when runoff levels are typically low in Finland. As estimated from the hydrograph of the Lepsämänjoki, the measurement periods accounted for $83 \%$ of the total water flow in the study period. Additional turbidity data (YSI sensors) from earlier studies (Särkelä et al. 2006, Valkama et al. 2007b) was also used when comparing the Nummenpää and the reference catchments, where automated water quality monitoring has been carried out since September 2005. In the reference catchment, turbidity was measured with an s::can (s::can GmbH, Austria) sensor in addition to the YSI sensor (Valkama et al. 2008).

To obtain reference data for the sensors and to analyse a larger set of variables than would have been possible with the sensor alone, a total of 123 manual runoff samples were taken. The samples from the central and lower sites corresponded to the depth and time of the sensor recordings. The upper site was sampled only infrequently, to estimate the background load from the forested area. The sampling occasions were chosen to represent different runoff situations, with a special emphasis on high-flow events. The manual samples from the reference catchment were taken on the same day, generally within two hours, as in the central and lower site in Nummenpää. The samples were analysed for temperature, conductivity, turbidity, total suspended solids, total $\mathrm{P}$, total dissolved $\mathrm{P}$, dissolved reactive $\mathrm{P}$, total $\mathrm{N}$, the sum of $\mathrm{NO}_{2}-\mathrm{N}$ and $\mathrm{NO}_{3}-\mathrm{N}, \mathrm{NH}_{4}-\mathrm{N}$, total $\mathrm{Fe}, \mathrm{SO}_{4}$ and other major anions and cations. Most of the analyses were performed in the laboratory of the Finnish Environment Institute, a testing laboratory accredited to the requirements of the standard SFS-EN ISO/IEC 17025. Samples taken in 2005-2007 from the Nummenpää catchment and all samples from the reference catchment were analysed at MetropoliLab, which is also an accredited laboratory.

Runoff was obtained by means of a V-notch weir constructed at the central site. The site was visited frequently to check the operation of the runoff measurement devices. On a number of occasions, the recorded runoff values were obviously incorrect due to snow pack or temporary leaking of the weir. In these relatively rare events, runoff values were corrected using expert judgement based, for example, on visual inspection and linear interpolation between previous and later runoff measurements. The central site was equipped with a precipitation recorder. Runoff at the upper and lower site was assumed to be the same as at the central site.

\section{Water quality determinations}

The presence of $\mathrm{P}$ was analysed by the molybdenum blue method (Murphy and Riley 1962), with ascorbic acid as a reducing agent. For the analysis of total $P$, the sample was first digested by acid peroxodisulphate at $120^{\circ} \mathrm{C}$ and under pressure. Total dissolved $\mathrm{P}$ and dissolved reactive $\mathrm{P}$ were analysed for a filtered sample (Whatman Nuclepore polycarbonate, pore size $0.4 \mu \mathrm{m}$, diameter $47 \mathrm{~mm}$ ); in the analysis of total dissolved $\mathrm{P}$, the sample was digested before staining, whereas dissolved reactive $P$ was determined without digestion. Particulate $P$ was obtained as total $\mathrm{P}$ less total dissolved $\mathrm{P}$, except in the reference catchment, where given the lack of analysis of total dissolved $P$, it was calculated as total $P$ less dissolved reactive $P$. No major bias is anticipated here, dissolved reactive P making the majority of total dissolved $P$ in Nummenpää runoff. Dissolved unreactive $P$ was calculated by subtracting dissolved reactive $P$ from total dissolved $P$.

Turbidity of the samples taken manually was measured nephelometrically (from scattering) with a Hach 2100AN IS turbidometer. If turbidity exceeded 1000 FNU (Formazine Nephelometric Units), the sample was diluted with 
deionised water. The YSI sensor also determined turbidity from scattering, but in Nephelometric Turbidity Units (NTU), by emitting near-infrared light into the water and measuring the light that bounces back at a $90^{\circ}$ angle from the suspended particles. Occasionally, turbidity exceeded the upper detection limit of the sensor (approximately 1000 NTU). The first sensor deployed at the lower site had an exceptionally low upper detection limit (about 850 NTU) and was soon replaced by another. The s::can sensor, used in the reference catchment, measured turbidity based on UV-VIS spectrometry. The results obtained by this sensor were calibrated against turbidity values measured in the laboratory $\left(r^{2}=0.98, n=26\right)$. Total suspended solids were analysed gravimetrically using the Whatman Nuclepore polycarbonate membrane.

Total $\mathrm{N}$ determination was initiated by digestion with peroxodisulphate in a buffered alkaline system, followed by reduction of $\mathrm{NO}_{3}$ with a Cd amalgam and determination of $\mathrm{NO}_{2}$ by the azo colour method. The sum of $\mathrm{NO}_{3}-\mathrm{N}$ and $\mathrm{NO}_{2}-\mathrm{N}$ were analysed using the same basic procedure as described above and $\mathrm{NH}_{4}-\mathrm{N}$ was analysed by the indophenol blue method.

The presence of cations ( $\mathrm{Na}, \mathrm{K}, \mathrm{Mg}, \mathrm{Ca}$ ) were determined with ICP-OES after centrifuging to remove most of the particles. Anions $\left(\mathrm{Cl}, \mathrm{F}, \mathrm{SO}_{4}\right)$ were determined with IC, which should only capture dissolved ions. Note that the results for $\mathrm{SO}_{4}\left(\mathrm{mg} \mathrm{l}^{-1}\right)$ include the oxygen atoms in the anion, i.e. they do not refer to $\mathrm{SO}_{4}-\mathrm{S}$. Apart from $\mathrm{SO}_{4}$, data on cations and anions is only available for the post-gypsum period.

\section{Source apportionment}

A source apportionment was made to estimate the share of agricultural P in the total load. Of the 73 inhabitants, 58 lived in houses with just a septic tank with overflow to a ditch, or in houses for which no information on the treatment system was available (Autio K, personal communication). Their P loading was set, according to the Onsite Wastewater System Decree (209/2003), at the national average of $0.80 \mathrm{~kg} \mathrm{y}^{-1}$, of which $60 \%$ (Rontu and Santala 1995) was assumed to be transported to surface water. The remaining 15 inhabitants lived in houses with an improved treatment of at least some fraction of the wastewaters. For these inhabitants, the amount of P in different wastewater types (all waters and grey waters) was taken from the above-mentioned decree and, in the absence of local data, a 70\% reduction in $\mathrm{P}$ was assumed, as required by the decree. In cases where wastewaters were transported to a municipal treatment plant outside the catchment, the load was assumed to be zero. The specific loads for forested $\left(0.09 \mathrm{~kg} \mathrm{ha}^{-1} \mathrm{y}^{-1}\right)$ and agricultural land $\left(1.1 \mathrm{~kg} \mathrm{ha}^{-1} \mathrm{y}^{-1}\right)$ and for natural background loss $(0.054$ $\mathrm{kg} \mathrm{ha}^{-1} \mathrm{y}^{-1}$ ) in southern Finland were obtained from the literature (Vuorenmaa et al. 2002, Mattsson et al. 2003).

\section{Statistical analyses}

The change in soil chemistry over time was studied by using repeated measures ANOVA with SAS Proc Mixed (SAS for Windows, SAS Institute Inc., Cary, NC). The impact of gypsum on P losses cannot be estimated by simply comparing the concentration levels before and after the amendment, as other factors affecting P concentrations may be present too. Fortunately, agricultural practices appeared to remain practically the same during the study period. The effect of fluctuating hydrological conditions was taken into account by analysing the difference in the relationship between turbidity and the concentrations of particulate and dissolved $\mathrm{P}$ and flow before and after the gypsum amendment, with the aid of the analysis of covariance (with SAS Proc GLM). In the covariance model, gypsum application was set as a qualitative and runoff volume as a quantitative variable with interaction taken into account.

\section{Results and discussion}

\section{Soil analyses}

The soil test P values before gypsum amendment averaged $20 \mathrm{mg} \mathrm{l}^{-1}$ over all the fields (range 8.4-86 mg l-1); $50 \mathrm{mg}^{-1}$ $\mathrm{I}^{-1}$ for cabbage fields and $16 \mathrm{mg} \mathrm{l}^{-1}$ for spring cereal fields. All these values exceeded the national average (about $12 \mathrm{mg} \mathrm{l}^{-1}$ ) and the agricultural optimum for cereals (Valkama et al. 2011). Soil pH ranged from 5.9 to 7.6 (arithmetic mean 6.6). Table 2 shows the development of soil chemistry in the 17 GPS-defined sites. After the gypsum amendment, the mean conductivity of the soil/water suspension increased by about $50 \%$ from the initial level of $170 \mu \mathrm{S} \mathrm{cm}^{-1}$. In addition, $\mathrm{S}$ also increased, but its development showed more fluctuation. By contrast, soil test $\mathrm{P}$ remained at the pre-gypsum level (mean $41 \mathrm{mg} \mathrm{l}^{-1}$ ). No change was found in $\mathrm{pH}, \mathrm{Ca}, \mathrm{K}$ or $\mathrm{Mg}$ (Table 2). 
Table 2. Development of soil chemistry in the 17 monitored sites. Means and their $95 \%$ confidence intervals. Shaded column represents the pre-gypsum period. $* * *$ increase with $p<0.001$.

\begin{tabular}{lcccccc}
\hline Variable & Autumn 2008 & Spring 2009 & Autumn 2009 & Spring 2010 & Autumn 2010 & Spring 2011 \\
\hline $\mathrm{pH}$ & $6.9 \pm 0.3$ & $6.9 \pm 0.3$ & $6.8 \pm 0.4$ & $6.9 \pm 0.4$ & $6.9 \pm 0.4$ & $6.9 \pm 0.3$ \\
Conductivity $\mathrm{\mu S} \mathrm{cm}$ - $^{-1 * * *}$ & $170 \pm 24$ & $220 \pm 31$ & $290 \pm 46$ & $220 \pm 32$ & $270 \pm 69$ & $300 \pm 59$ \\
$\mathrm{P} \mathrm{mg} \mathrm{l}^{-1}$ & $41 \pm 16$ & $40 \pm 16$ & $40 \pm 18$ & $41 \pm 16$ & $38 \pm 21$ & $36 \pm 18$ \\
$\mathrm{~S} \mathrm{mg} \mathrm{l}^{-1 * * *}$ & $35 \pm 11$ & $77 \pm 30$ & $87 \pm 26$ & $55 \pm 23$ & $67 \pm 26$ & $48 \pm 19$ \\
$\mathrm{~K} \mathrm{mg} \mathrm{l}^{-1}$ & $290 \pm 35$ & $300 \pm 36$ & $320 \pm 34$ & $300 \pm 41$ & $320 \pm 34$ & $300 \pm 35$ \\
$\mathrm{Ca} \mathrm{mg} \mathrm{l}^{-1}$ & $4400 \pm 930$ & $4400 \pm 950$ & $4700 \pm 1000$ & $4200 \pm 1200$ & $4300 \pm 900$ & $4600 \pm 1100$ \\
$\mathrm{Mg} \mathrm{mg} \mathrm{l}^{-1}$ & $400 \pm 87$ & $420 \pm 86$ & $420 \pm 83$ & $420 \pm 95$ & $450 \pm 89$ & $430 \pm 86$ \\
\hline
\end{tabular}

\section{Runoff quality: Turbidity and particulate $\mathrm{P}$}

As found in other Finnish agricultural catchments (Valkama et al. 2007a, Linjama et al. 2009, Koskiaho et al. 2010), the turbidity recorded by the online sensors in Nummenpää correlated with the turbidity determined in the laboratory (Turbidity $_{\text {Lab }}=0.77$ Turbidity $_{\text {Online }}+4.2, r^{2}=0.95, n=117$ ). Before the gypsum amendment, the turbidity values increased with flow (Fig. 2). The scatter in the relationship was partly brought about by the fact that turbidity tended to be higher for a rising than a decreasing flow. After the gypsum amendment, turbidity values were lower and their correlation to the flow weaker. Before the amendment, turbidity increased at the lower site by 2.95 NTU (95\% confidence interval 2.83-3.07 NTU) when flow increased by one unit (l s $\left.{ }^{-1}\right)$; thereafter, the increase was only 0.72 NTU ( $95 \%$ confidence interval $0.70-0.75$ NTU). Yet, some high turbidity values were also seen after the amendment (Fig. 2).

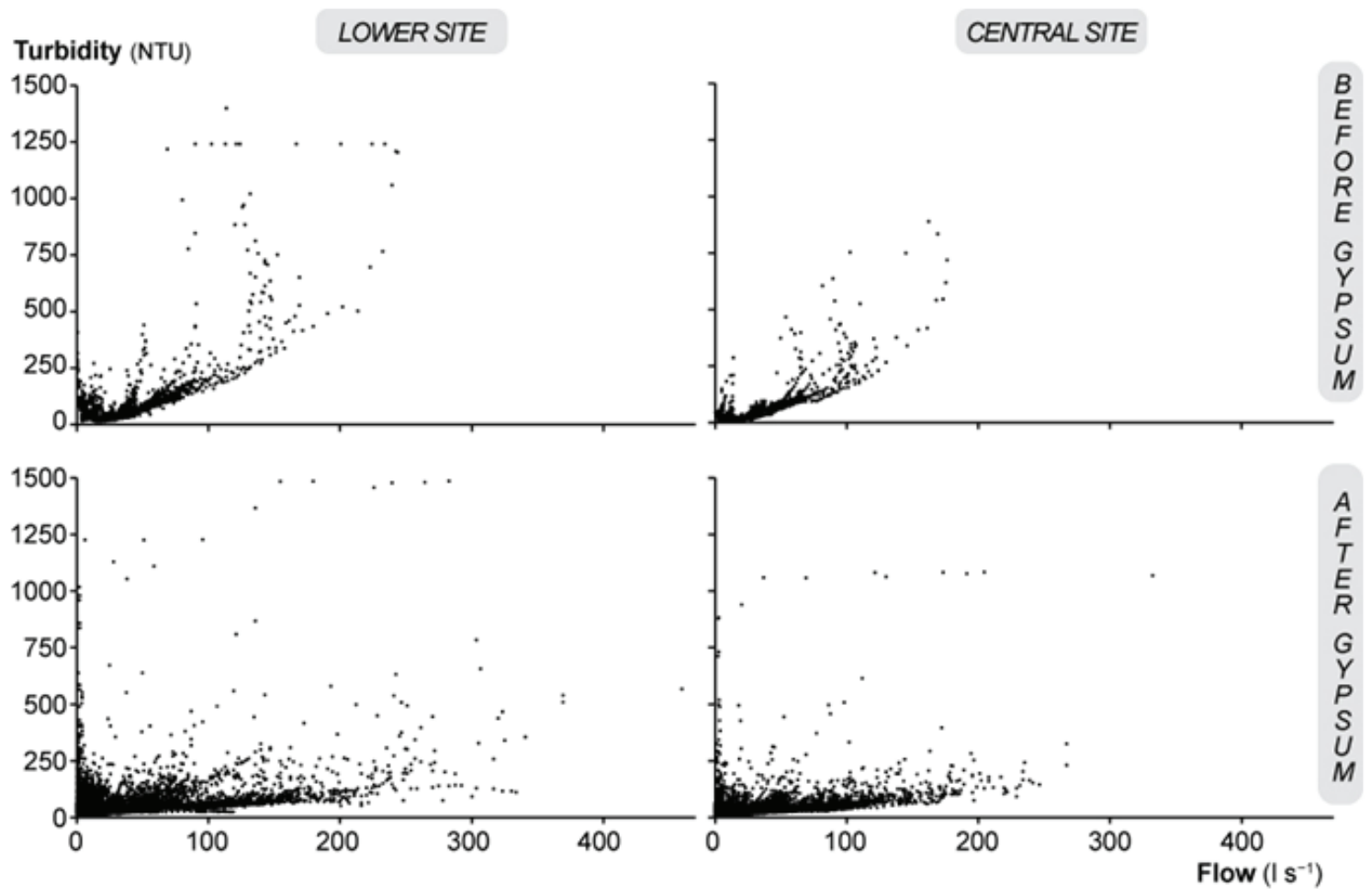

Fig. 2. Turbidity and flow before ( 2313 hourly values) and after ( 8761 hourly values) the gypsum amendment at the lower and central sites in the Nummenpää catchment.

There was also a correlation between turbidity recorded online and the concentration of particulate $P\left(C_{p p}, \mu g\right.$ $\left.\mathrm{I}^{-1}\right)$ determined in the laboratory from manual samples $\left(C_{P P}=1.4\right.$ Turbidity $\left._{\text {Online }}+7.9, r^{2}=0.92, n=117\right)$. Accordingly, online data could be used as a proxy for the changes in particulate $\mathrm{P}$ caused by the gypsum amendment. 
The covariance analysis gave the following equations for the relationship between the concentration of particulate $\mathrm{P}$ and flow $\left(\mathrm{I} \mathrm{S}^{-1}\right)$ :

Before gypsum: $C_{\mathrm{Pp}}=-17+4.6$ Flow

After gypsum: $\mathrm{C}_{\mathrm{pp}}=46+1.1$ Flow

The model (and the intercepts and slopes of the equations) was significant with $p<0.001$ ( $n=15,321$ ), although due to strong autocorrelation in the data, the probability values are overestimated to some extent. The equations were then used to estimate the concentration of particulate $P$ for all the seven measurement periods in spring 2008 - spring 2011, supposing that gypsum was already applied at the start of the study period or that it had not been used at all. In using this approach, the mean reduction in the loss of particulate P due to gypsum was $64 \%$. Table 3 shows the observed and predicted losses of particulate $P$ for each measurement period. The autumn of 2010 was very dry. The higher intercept value given by the covariance model for the post-gypsum than pre-gypsum period (46 vs. $-17 \mu \mathrm{g} \mathrm{I}^{-1}$, respectively) accounts for the negative reduction for particulate P predicted for this season with very low flow values.

Table 3. Characteristics of the measurement periods and the observed fluxes of particulate $P$ in these periods. In addition, the predicted fluxes of particulate $P$ supposing that gypsum was applied already during the first period or that it had not been used at all.

\begin{tabular}{|c|c|c|c|c|c|c|c|c|}
\hline \multirow[t]{3}{*}{ Period } & & \multirow{3}{*}{$\begin{array}{l}\text { Duration } \\
\text { (d) }\end{array}$} & \multirow{3}{*}{$\begin{array}{l}\text { Precipitation } \\
(\mathrm{mm})\end{array}$} & \multirow{3}{*}{$\begin{array}{l}\text { Runoff } \\
\text { (mm) }\end{array}$} & \multicolumn{4}{|c|}{ Particulate $\mathrm{P}$} \\
\hline & & & & & \multirow{2}{*}{$\begin{array}{l}\text { Observed } \\
(\mathrm{kg})\end{array}$} & \multicolumn{3}{|c|}{ Predicted } \\
\hline & & & & & & $\begin{array}{l}\text { No gypsum } \\
(\mathrm{kg})\end{array}$ & $\begin{array}{l}\text { Gypsum } \\
\text { (kg) }\end{array}$ & $\begin{array}{l}\text { Change } \\
(\%)\end{array}$ \\
\hline Before gypsum & Spring '08 & 90 & $141^{1}$ & 109 & 70.1 & 78.0 & 31.1 & -60 \\
\hline $\begin{array}{l}\text { Gypsum } \\
\text { amendment }\end{array}$ & Autumn '08 & 135 & 318 & 177 & 54.5 & 170.4 & 60.4 & -65 \\
\hline \multirow[t]{5}{*}{ After gypsum } & Spring '09 & 95 & 96 & 59 & 32.0 & 50.0 & 18.6 & -63 \\
\hline & Autumn '09 & 109 & 191 & 41 & 6.6 & 13.2 & 8.0 & -40 \\
\hline & Spring '10 & 92 & 215 & 136 & 51.6 & 146.2 & 49.9 & -66 \\
\hline & Autumn '10 & 86 & 131 & 11 & 1.6 & 1.4 & 1.6 & +18 \\
\hline & Spring '11 & 92 & 60 & 79 & 20.5 & 105.5 & 33.7 & -68 \\
\hline Sum & & 697 & 1151 & 611 & & 564.8 & 203.4 & -64 \\
\hline
\end{tabular}

${ }^{1}$ Data from a nearby site (Tuusula)

\section{Runoff quality: dissolved reactive $P$}

The concentration of dissolved reactive $P\left(C_{D R P}\right)$ could not be estimated from the online data. Since there was only very infrequent manual data available, the effect of gypsum on this $P$ form is more uncertain than in the case of particulate P. Before gypsum amendment, the mean concentration of dissolved reactive $\mathrm{P}$ on the lower site was $48 \mathrm{\mu g} \mathrm{I}^{-1}$ (Table 4) with the concentrations increasing with runoff. After gypsum, the mean concentration of dissolved reactive $\mathrm{P}$ was $36 \mu \mathrm{g} \mathrm{l^{-1 }}$ and the correlation with flow was weak (data not shown). At the central site, the same pattern was found. Analysis of covariance gave the following equations for the lower site:

Before gypsum: $C_{D R P}=16+0.48$ Flow

After gypsum: $\mathrm{C}_{\mathrm{DRP}}=34+0.08$ Flow

However, the model had a $p$-value of $0.077(n=50)$, being only 'borderline' significant; here, there was no autocorrelation bias due to relatively infrequent sampling. The use of these equations for the spring $2008-$ spring 2011 data, in a similar fashion as was done for particulate P, suggested that the loss of dissolved reactive P was $29 \%$ lower after the gypsum amendment. 
Table 4. Water quality before and after gypsum amendment in the lower site in Nummenpää catchment. Means and their $95 \%$ confidence intervals.

\begin{tabular}{|c|c|c|c|c|}
\hline \multirow[t]{2}{*}{ Variable } & \multirow{2}{*}{$\begin{array}{c}\text { Before gypsum } \\
n=13\end{array}$} & \multicolumn{3}{|c|}{ After gypsum } \\
\hline & & $\begin{array}{l}1^{\text {st }} \text { year } \\
n=11\end{array}$ & $\begin{array}{c}2^{\text {nd }} \text { year } \\
n=13\end{array}$ & $\begin{array}{c}3^{\text {rd }} \text { year } \\
n=12\end{array}$ \\
\hline $\mathrm{pH}$ & $7.0 \pm 0.1$ & $6.9 \pm 0.2$ & $6.8 \pm 0.3$ & $7.1 \pm 0.1$ \\
\hline Conductivity ( $\mathrm{mS} \mathrm{m}^{-1}$ ) & $13 \pm 1.4$ & $22 \pm 4.4$ & $29 \pm 8.8$ & $20 \pm 5.1$ \\
\hline Turbidity (FNU) & $240 \pm 230$ & $110 \pm 75$ & $59 \pm 42$ & $37 \pm 27$ \\
\hline Total suspended solids $\left(\mathrm{mg} \mathrm{l}^{-1}\right)$ & $210 \pm 210$ & $93 \pm 66$ & $46 \pm 27$ & $28 \pm 19$ \\
\hline Total P $\left(\mu \mathrm{g} \mathrm{I}^{-1}\right)$ & $360 \pm 280$ & $170 \pm 89$ & $110 \pm 45$ & $87 \pm 36$ \\
\hline Particulate $\mathrm{P}\left(\mu \mathrm{gl}^{-1}\right)$ & $300 \pm 270$ & $130 \pm 84$ & $64 \pm 33$ & $39 \pm 15$ \\
\hline Dissolved reactive $\mathrm{P}\left(\mu \mathrm{g}^{-1}\right)$ & $48 \pm 16$ & $34 \pm 29$ & $36 \pm 15$ & $41 \pm 24$ \\
\hline Dissolved unreactive $\mathrm{P}\left(\mu \mathrm{g} \mathrm{I}^{-1}\right)$ & $6.8 \pm 1.6$ & $7.7 \pm 2.6$ & $7.2 \pm 0.9$ & $7.4 \pm 1.3$ \\
\hline Total N $\left(\mu \mathrm{g} \mathrm{I}^{-1}\right)$ & $3000 \pm 770$ & $2200 \pm 550$ & $4700 \pm 2100$ & $4000 \pm 3200$ \\
\hline $\mathrm{NO}_{23}-\mathrm{N}\left(\mu \mathrm{g} \mathrm{I}^{-1}\right)$ & $2200 \pm 630$ & $1300 \pm 460$ & $3900 \pm 2000$ & $3600 \pm 3300$ \\
\hline $\mathrm{NH}_{4}-\mathrm{N}\left(\mu \mathrm{gl}^{-1}\right)$ & $27 \pm 10$ & $70 \pm 53$ & - & - \\
\hline $\mathrm{Fe}\left(\mu \mathrm{gl}^{-1}\right)$ & $12000 \pm 9900$ & $5400 \pm 4200$ & - & - \\
\hline $\mathrm{SO}_{4}\left(\mathrm{mg} \mathrm{l}^{-1}\right)$ & $13 \pm 1.4$ & $61 \pm 35$ & $69 \pm 30$ & $30 \pm 11$ \\
\hline $\mathrm{Cl}\left(\mathrm{mg}^{-1}\right)$ & - & $5.7 \pm 2.1$ & $8.7 \pm 2.3$ & $7.2 \pm 1.1$ \\
\hline $\mathrm{F}\left(\mu \mathrm{g} \mathrm{l}^{-1}\right)$ & - & $220 \pm 26$ & $230 \pm 30$ & $250 \pm 35$ \\
\hline $\mathrm{Na}\left(\mathrm{mg} \mathrm{l}^{-1}\right)$ & - & $5.6 \pm 1.3$ & $6.6 \pm 1.3$ & $6.3 \pm 1.2$ \\
\hline $\mathrm{K}\left(\mathrm{mg} \mathrm{l}^{-1}\right)$ & - & $3.8 \pm 1.3$ & $3.4 \pm 0.9$ & $3.2 \pm 0.9$ \\
\hline $\mathrm{Ca}\left(\mathrm{mg} \mathrm{l}^{-1}\right)$ & - & $28 \pm 12$ & $32 \pm 11$ & $19 \pm 6.7$ \\
\hline $\mathrm{Mg}\left(\mathrm{mgl}^{-1}\right)$ & - & $9.0 \pm 2.3$ & $12 \pm 3.6$ & $7.6 \pm 2.2$ \\
\hline
\end{tabular}

\section{Runoff quality: cations and anions}

The reliability of determinations of ion concentrations was evaluated by 1) examining the balance of anions and cations (in meq ${ }^{-1}$ ) and 2) comparing the calculated and the measured conductivity. The first approach revealed a slight surplus of cations (Cations $=1.1$ Anions $+1.3, r^{2}=0.93, n=108$ ). Overestimating cations may result from the analysis with ICP-OES, which can capture cations on/in particles, in addition to those in solution, because of the only modest pre-treatment of samples (centrifuging). By contrast, anions were analysed by IC, which had a pre-filtration and a pre-colony that prevents particulates entering the measurement colony. The calculated conductivity $\left(\mathrm{mS} \mathrm{m}^{-1}\right)$ strongly correlated with the observed one, again with slight overestimation (Calculated $=1.3$ Observed $-4.6, r^{2}=0.96, n=108$ ). Yet, based on these two relationships, the ion determinations can be considered sufficiently reliable for the purpose of the study-i.e. to examine whether gypsum triggered major changes in the losses of ions, particularly $\mathrm{SO}_{4}$.

$\mathrm{SO}_{4}$ concentrations correlated strongly with Ca concentrations (data not shown), yet the molar ratio of $\mathrm{SO}_{4}$ and $\mathrm{Ca}$ in runoff was not that of gypsum used (1:1) but 1:0.79. $\mathrm{SO}_{4}$ at circumneutral pH has a relatively low tendency to be adsorbed on soil particles, whereas $\mathrm{Ca}$ may be taken up by exchange reactions. Such an exchange reaction may result in enhanced losses of Mg and K (Shainberg et al. 1989, Uusitalo et al. 2012). Unfortunately, no data on these cations exist from the pre-gypsum period, which prevents analysing whether Mg or K losses have increased due to gypsum amendment. According to soil analyses (see above), no change in $\mathrm{Mg}$ or $\mathrm{K}$ was found.

\section{Potential side effects: $\mathrm{F}$ and $\mathrm{SO}_{4}$}

Theoretically, F pollution could form an adverse side effect of the amendment. There was no data on $\mathrm{F}$ in Nummenpää runoff before the gypsum treatment. After the gypsum, the maximum $\mathrm{F}$ concentration was $0.32 \mathrm{mg} \mathrm{I}^{-1}$ at the lower site and $0.16 \mathrm{mg} \mathrm{l}^{-1}$ at the upper site, not affected by gypsum. Given that the upper limit for $\mathrm{F}$ in the EU's Drinking Water Directive (98/83/EC) is $1.5 \mathrm{mg} \mathrm{l}^{-1}, \mathrm{~F}$ appears not to pose problems. 
The losses of $\mathrm{SO}_{4}$ give an estimate of the duration of gypsum effect. In addition, they give an insight into another potential side effect: the risk of $\mathrm{SO}_{4}$-mediated eutrophication (Smolders et al. 2006). The effect of $\mathrm{SO}_{4}$ on freshwater ecology has not been considered in earlier studies examining the use of gypsum in agriculture, perhaps due to the fact that $\mathrm{SO}_{4}$ is considered harmless, as in the thorough review by Shainberg et al. (1989). Yet, $\mathrm{SO}_{4}$ losses could undermine the beneficial effect of gypsum on P losses by increasing P availability in freshwater bodies. In eutrophic lakes, $\mathrm{SO}_{4}$ tends to promote $\mathrm{SO}_{4}$ reduction in surface sediments, which can greatly increase the release of benthic $\mathrm{P}$ by immobilising Fe in sediments (e.g. Smolders and Roelofs 1993).

The concentration of $\mathrm{SO}_{4}\left(\mathrm{C}_{50}\right)$ in the manual samples showed a close relationship with the conductivity recorded by the online sensors $\left(\mathrm{C}_{\mathrm{SO}}=0.26\right.$ Conductivity $\left.{ }^{1.63}, r^{2}=0.84, n=117\right)$. Using this relationship, the losses of $\mathrm{SO}_{4}$ were $^{2}$ calculated for the central and lower site from the online data. For the upper site, only manual samples were used. Assuming that the spring 2008 data represented the entire year, the $\mathrm{SO}_{4}$ losses were $44 \mathrm{~kg} \mathrm{ha}^{-1} \mathrm{y}^{-1}$ in the forested upper reaches and $140 \mathrm{~kg} \mathrm{ha}^{-1} \mathrm{y}^{-1}$ for agricultural land before the amendment. Soon after the gypsum amendment, the $\mathrm{SO}_{4}$ concentrations increased substantially (Table 4). As there were heavy rains before the surface-applied gypsum was incorporated in the soil by tillage practices, some of the $\mathrm{SO}_{4}$ in runoff may be due to the direct washout of the gypsum. After the first autumn, the losses were smaller; yet the mean was as high as $460 \mathrm{~kg} \mathrm{ha}^{-1} \mathrm{y}^{-1}$.

$\mathrm{SO}_{4}$ losses from agriculture are a rarely-studied topic in Finland. Korkman (1973) estimated that the mean loss was $24 \mathrm{~kg} \mathrm{ha}^{-1} \mathrm{y}^{-1}$ in the 1960s, while Turtola and Jaakkola (1986) found $\mathrm{SO}_{4}$ losses of $48 \mathrm{~kg} \mathrm{ha}^{-1} \mathrm{y}^{-1}$ from a clayey soil under barley and grass in 1980-1982. More recent data (from a database of the Finnish Environment Institute) show that the losses are 42-180 kg ha-1 $\mathrm{y}^{-1}$ in agricultural small catchments in southern Finland but as high as $920 \mathrm{~kg} \mathrm{ha}^{-1} \mathrm{y}^{-1}$ in catchments on acid sulphate soils in western Finland.

The total amount of gypsum spread in the Nummenpää catchment was 369 tonnes. Given that the moisture content of the gypsum was $16.5 \%$, a total of 172 tonnes of $\mathrm{SO}_{4}$ was applied in gypsum. An upper limit of the gypsum loss can be obtained by assuming that all $\mathrm{SO}_{4}$ lost from agricultural land after the gypsum amendment originated from gypsum. In this case, $60 \%$ of the gypsum had been lost in runoff in three years. The true figure is smaller, as a substantial part of $\mathrm{SO}_{4}$ loss may be related to mineralisation rather than gypsum; well over $95 \%$ of total $\mathrm{S}$ in many soils was held in the organic matter (Nriagu 1978). In addition, $\mathrm{SO}_{4}$ is added to soil in fertilisers (Yli-Halla et al. 2011).

Losses of $\mathrm{SO}_{4}$ have been found to increase with the field percentage of a catchment (Korkman 1973, Mattsson et al. 2007). Therefore, agriculture not only increases the losses of $\mathrm{P}$ but also those of $\mathrm{SO}_{4}$. In this context, it is very challenging to estimate the effect of gypsum-based $\mathrm{SO}_{4}$ on freshwater eutrophication. In the Netherlands, $\mathrm{SO}_{4}$ has caused major deterioration of the fen systems and riverine floodplains (Loeb 2008), with the Rhine being the source of $\mathrm{SO}_{4}$-rich waters. The present-day mean concentration of $60 \mathrm{mg} \mathrm{l}^{-1}$ in the Rhine (Loeb 2008) can be compared with the runoff concentration of $13 \mathrm{mg} \mathrm{l}^{-1}$ in Nummenpää before the gypsum amendment and with the annual mean of 30-69 $\mathrm{mg} \mathrm{l}^{-1}$ after the amendment (Table 4). Since $\mathrm{SO}_{4}$ may pose a risk for freshwater systems, massive-scale use of gypsum is not recommended in catchments with $\mathrm{SO}_{4}$-poor eutrophic lakes. Under such conditions, the balance between decreased $\mathrm{P}$ losses and increased $\mathrm{SO}_{4}$ losses remains to be resolved.

\section{Source apportionment}

Estimating the effect of gypsum at a catchment scale has its merits and disadvantages. Our results on the reduction of $\mathrm{P}$ losses due to gypsum use are approximately at the same level as the results obtained in the laboratory extractions of gypsum-treated clayey soil with artificial rain (Uusitalo et al. 2012) and in a field-scale modelling exercise (Jaakkola et al. 2012). When compared with lab- or plot-scale studies, the evidence from a catchmentscale experiment can be considered more universal, because they average the results over a larger variety of conditions than is usually present in smaller scale studies. However, the accuracy of the result is bound to be lower, because it is not possible to account for, let alone govern, all potentially affecting factors at a catchment scale, including climatic conditions. Fortunately, the three years after the gypsum amendment included both wet and dry autumns and cold and mild winters, and thus our results should in this respect be representative of average conditions in southern Finland.

A major potential source of error at the catchment scale is source apportionment. According to the specific load values taken from literature for forestry, sparse population and agriculture, the annual $\mathrm{P}$ flux at the upper site should have been $0.12 \mathrm{~kg} \mathrm{ha}^{-1} \mathrm{y}^{-1}$. However, a lower value $\left(0.07 \mathrm{~kg} \mathrm{ha}^{-1} \mathrm{y}^{-1}\right)$ was obtained using the water quality monitoring data at the site, which may be due to manual sampling missing the peak load events or to an untypically low load from forestry (the main land use type in the upper reaches). 
By contrast, for the entire catchment and the period before the gypsum amendment, the P loss calculated from the specific load values was $37 \%$ lower than the flux obtained from monitoring data. If the load estimates for other sources than agriculture were correct, the specific load for agriculture was as high as $1.7 \mathrm{~kg} \mathrm{ha}^{-1} \mathrm{y}^{-1}$, a value that is within realistic bounds, taking into account the high $\mathrm{P}$ level, erosivity of the soil and the lack of winter vegetation cover in most of the fields (see Puustinen et al. 2010). If so, $79 \%$ of the total P flux from the Nummenpää catchment originated from the fields (before the gypsum amendment). Because gypsum can only have affected this part of the $\mathrm{P}$ losses, the actual reduction in the agricultural losses has been somewhat higher than that presented above, which was interpreted from the results representing the entire catchment.

\section{Reference catchment}

Further evidence of a major change in $\mathrm{P}$ losses due to gypsum application was obtained when the monitoring data of the Nummenpää catchment was contrasted to that of the reference catchment. Figure 3 shows turbidity recordings made at the same time in these two catchments before and after the gypsum amendment in Nummenpää. The comparison shows a change towards lower turbidity values in the Nummenpää catchment after the gypsum amendment, although the highest values had decreased during the same period in the reference catchment, too. Before the gypsum amendment the turbidity values in Nummenpää were approximately 1.1 times those in the reference catchment (as shown by the slope of the regression equation, Fig. 3), but after the amendment the ratio was lowered to almost 0.5 , with much more scatter in the relationship as indicated by the low $r^{2}$ value.
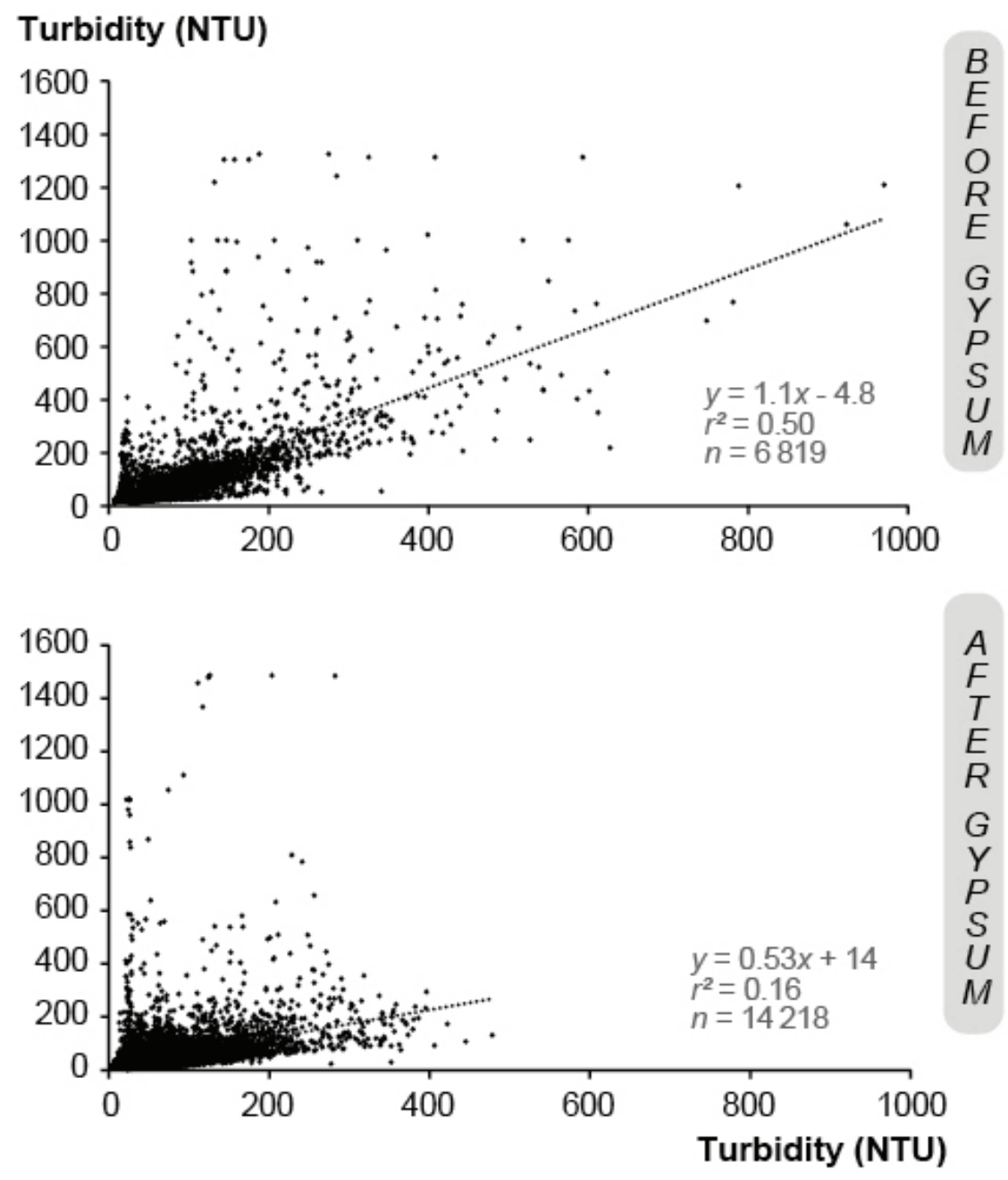

Fig. 3. Relationship between turbidity recordings performed at the same time (within 30 minutes) in the Nummenpää and the reference catchment before ( autumn 2005 - spring 2008) and after (autumn 2005 - autumn 2010) gypsum was applied in Nummenpää. Determinations by the YSI sensor, or the calibrated s::can sensor. 
A similar comparison between the Nummenpää and the reference catchment was made on the basis of total suspended solids, particulate $\mathrm{P}$ and dissolved reactive $\mathrm{P}$ concentrations analysed in the laboratory from the manual samples taken on the same day at both sites. Before the gypsum amendment, the concentrations of total suspended solids in these two catchments correlated with each other, and total suspended solids in the Nummenpää catchment, $\mathrm{C}_{\mathrm{TSS}}$, being approximately 1.1 times those in the reference catchment, $\mathrm{C}_{\mathrm{TSS}{ }^{*}}\left(\mathrm{C}_{\mathrm{TSS}}=1.11 \mathrm{C}_{\mathrm{TSS}}{ }^{*}-4.10\right.$, $\left.r^{2}=0.43, n=46\right)$. After the gypsum amendment, the correlation was weaker and the concentrations in the Nummenpää catchment tended to be lower than in the reference catchment $\left(\mathrm{C}_{\mathrm{TSS}}=0.65 \mathrm{C}_{\mathrm{TSS} *}+14.4, r^{2}=0.25, n=27\right)$. For particulate $\mathrm{P}$ a similar change was found; before the gypsum amendment the relationship was $\mathrm{C}_{\mathrm{pP}}=1.15 \mathrm{C}_{\mathrm{pp} *}$ $-5.94, r^{2}=0.51$, and after the gypsum amendment it was $C_{p P}=0.57 C_{p p *}+32.0, r^{2}=0.19$. (Note that in this analysis, particle $\mathrm{P}$ was calculated by subtracting dissolved reactive $\mathrm{P}$ from total $\mathrm{P}$ ). Dissolved reactive $\mathrm{P}$ seemed to decrease as well, but the difference was smaller, i.e. before the gypsum the relationship was $C_{D R P}=1.24 C_{D R P *}+3.91$, $r^{2}=0.59$ and after the gypsum $C_{D R P}=1.08 C_{D R P *}+10.3, r^{2}=0.25$.

\section{Conclusions}

Agricultural water protection measures encompass a variety of actions, ranging from soil protection and balanced fertilisation to the implementation of buffer zones and the construction of wetlands. In addition to these measures, novel techniques provide an approach with potential to speed up nutrient reduction. In this catchmentscale experiment, gypsum amendment of agricultural soils led to a clear reduction in P fluxes. The fluxes of both particulate and dissolved P from the clayey Nummenpää catchment remained at a lower level for three years after the amendment. $\mathrm{SO}_{4}$ losses are an inherent side effect of gypsum amendment. Massive-scale use of gypsum is not recommended in catchments with $\mathrm{SO}_{4}$-poor eutrophic lakes, since $\mathrm{SO}_{4}$ may trigger the release of $\mathrm{P}$ from freshwater sediments.

\section{Acknowledgements}

This study formed part of the TraP project ('Novel gypsum-based products for farm scale phosphorus trapping') led by Yara Finland and funded by Yara, the Finnish Funding Agency for Technology and Innovation (Tekes) and the participating institutes. The studies at the reference site were funded by Maa- ja vesitekniikan tuki ry. We are grateful to Sakari Alasuutari and Reetta Palva (TTS) for collecting the soil samples, SYKE's laboratory for water quality analyses, Irmeli Ahtela (the Uusimaa ELY Centre) for help in the initial phases of the study, Irina Lähteenmaa (the Nurmijärvi municipality) for her communication with farmers and provision of local data, and all the farmers of the Nummenpää catchment for their positive attitude toward the catchment studies performed in their fields. Finally, we acknowledge the two referees and guest editor for their useful comments. This work was presented during a workshop organized within COST Action 869 in Jokioinen, Finland.

\section{References}

Aura, E., Saarela, K. \& Räty, M. 2006. Savimaiden eroosio. (In Finnish). MTT:n selvityksiä 118. Agrifood Research Centre. 32 p.

Ballantine, D.J. \& Tanner, C.C. 2010. Substrate and filter materials to enhance phosphorus removal in constructed wetlands treating diffuse farm runoff: A review. New Zealand Journal of Agricultural Research 53: 71-95.

Boruvka, L. \& Rechcigl, J.E. 2003. Phosphorus retention by the Ap horizon of a spodosol as influenced by calcium amendments. Soil Science 168: 699-706.

Caraco, N.F., Cole, J.J. \& Likens, G.E. 1989. Evidence for sulphate-controlled phosphorus release from sediments of aquatic systems. Nature 341: 316-318.

Cox, J.W., Varcoe, J.C.R., Chittleborough, D.J. \& van Leeuwen, J. 2005. Using gypsum to reduce phosphorus in runoff from subcatchments in South Australia. Journal of Environmental Quality 34: 2118-2128.

Elonen, P. 1971. Particle-size analysis of soil. Selostus: Maan raekoostumuksen määrittäminen. (In Finnish). Acta Agriculturae Fenniae 122: 1-122.

Elrashidi, M.A., West, L.T., Seybol, C.A., Benham, E.C., Schoeneberger, P.J. \& Ferguson, R. 2010. Effects of gypsum addition on solubility of nutrients in soil amended with peat. Soil Science 174: 162-172.

Favaretto, N., Norton, L.D., Joern, B.C. \& Brouder, S.M. 2006. Gypsum amendment and exchangeable calcium and magnesium affecting phosphorus and nitrogen in runoff. Soil Science Society of America Journal 70: 1788-1796.

Finnish Soil Database. 2010. Copyrigt by MTT Agrifood Research Finland, Finnish Forest Research Institute (Metla) and Geological Survey of Finland (GTK).

Grubb, K.L., McGrath, J.M., Penn, C.J. \& Bryant, R.B. 2011. Land application of spent gypsum from ditch filters: phosphorus source or sink? Agricultural Sciences 2: 364-374. 
Hasler, A.C. \& Einsele, W.G. 1948. Fertilization for increasing productivity of natural inland waters. Transactions of the North American Wildlife Conference 13: 527-555.

Ippolito, J.A., Barbarick, K.A. \& Elliott, H.A. 2011. Drinking water treatment residuals: A review of recent uses. Journal of Environmental Quality 40: 1-12.

Jaakkola, E., Tattari, S., Ekholm, P., Pietola, L., Posch, M. \& Bärlund, I. 2012. Simulated effects of gypsum amendment on phosphorus losses from agricultural soils. Agricultural and Food Science 21:292-306.

Kirkkala, T., Ventelä, A.-M., Tarvainen, M. 2012.Fosfilt filters in an agricultural catchment: a long-term field-scale experiment. Agricultural and Food Science 21: 237-246.

Korkman, J. 1973. Sulphur status of Finnish cultivated soils. Journal of the Scientific Agricultural Society of Finland 45: 121-215.

Koskiaho, J., Lepistö, A., Tattari, S. \& Kirkkala, T. 2010. On-line measurements provide more accurate estimates of nutrient loading: a case of the Yläneenjoki river basin, southwest Finland. Water Science \& Technology 62: 115-122.

Kumar, A. \& Saha, A. 2011. Effect of polyacrylamide and gypsum on surface runoff, sediment yield and nutrient losses from steep slopes. Agricultural Water Management 98: 999-1004.

Lillunen, A., Härjämäki, K., Riiko, K., Yli-Renko, M., Kulmala, A., Koskinen, J., Lundström, E. \& Kaasinen, S. 2011. Kotopellolta Rantalohkolle - Tehoa maatalouden vesiensuojeluun. TEHO-hankkeen (2008 - 2011) loppuraportti. (In Finnish). TEHO-Hankkeen juIkaisuja 5/2011. Tehoa maatalouden vesiensuojeluun. 153 p.

Linjama, J., Puustinen, M., Koskiaho, J., Tattari, S., Kotilainen, H. \& Granlund, K. 2009. Implementation of automatic sensors for continuous monitoring of runoff quantity and quality in small catchments. Agricultural and Food Science in Finland 18: 417-427.

Loeb, R. 2008. On biogeochemical processes influencing eutrophication and toxicity in riverine wetlands. PhD thesis, Nijmegen, Radboud Universiteit Nijmegen. Natuurwetenschappen, Wiskunde en Informatica. 173 p.

Mattsson, T., Finer, L., Kortelainen, P. \& Sallantaus, T. 2003. Brook water quality and background leaching from unmanaged forested catchments in Finland. Water, Air and Soil Pollution 147: 275-297.

Mattsson, T., Kortelainen, P., Lepistö, A. \& Räike, A. 2007. Organic and minerogenic acidity in Finnish rivers in relation to land use and deposition. Science of the Total Environment 383: 183-192.

Ministry of the Environment. 2009. Valtioneuvoston päätös Vuoksen, Kymijoen-Suomenlahden, Kokemäenjoen-SaaristomerenSelkämeren, Oulujoen-lijoen, Kemijoen, Tornionjoen sekä Tenojoen-Näätämöjoen-Paatsjoen vesienhoitoalueiden vesienhoitosuunnitelmista vuoteen 2015. (In Finnish). YM018:00/2009.

Murphy, J. \& Riley, J.P. 1962. A modified single solution method for the determination of phosphate in natural waters. Analytica Chimica Acta 27: 31-36.

Murphy, P.N.C. \& Stevens, R.J. 2010. Lime and gypsum as source measures to decrease phosphorus loss from soils to water. Water, Air and Soil Pollution 212: 101-111.

Muukkonen, P., Hartikainen, H. \& Alakukku, L. 2009. Boardmill sludge reduces phosphorus losses from conservation-tilled clay soil. Soil \& Tillage Research 104: 285-291.

Närvänen, A., Jansson, H., Uusi-Kämppä, J. \& Perälä, P. 2008. Phosphorus load from equine critical source areas and its reduction using ferric sulphate. Boreal Environment Research 13: 265-274.

Nriagu, J.O. (ed.). 1978. Sulfur in the environment. Part II. Ecological impacts. Wiley. 482 p.

Palva, R. \& Alasuutari, S. 2009. Levityskoneet kipsin peltolevitykseen. (In Finnish). TTS tutkimuksen tiedote. Luonnonvara-ala: maatalous 6/2009. $6 \mathrm{p}$

Pietola, L. 2008. Gypsum-based management practices to prevent phosphorus transportation. NJF 401 Proceedings on phosphorus management in Nordic-Baltic agriculture - reconciling productivity and environmental protection. NJF Report 4:79-83 .

Puustinen, M., Turtola, E., Kukkonen, M., Koskiaho, J., Linjama, J., Niinioja, R. \& Tattari, S. 2010. VIHMA - A tool for allocation of measures to control erosion and nutrient loading from Finnish agricultural catchments. Agriculture, Ecosystems and Environment 138: 306-317.

Rontu, M. \& Santala, E. 1995. Haja-asutuksen jätevesien käsittely. (In Finnish). Vesi- ja ympäristöhallituksen monistesarja 584. Vesi- ja ympäristöhallitus. Helsinki.

Särkelä, A., Lahti, K., Vahtera, H., Penttilä, S. \& Ahtela, I. 2006. Automaattinen veden laadun seuranta avuksi hajakuormituksen arviointiin. (In Finnish). Vesitalous 47: 20-25.

Shainberg, I., Sumner, M.E., Miller, W.P., Farina, M.P.W., Pavan, M.A. \& Fey, M.V. 1989. Use of gypsum on soils: A review. Advances in Soil Science 9: 1-111.

Smolders, A. \& Roelofs, J.G.M. 1993. Sulphate-mediated iron limitation and eutrophication in aquatic ecosystems. Aquatic Botany 46: 247-253.

Smolders, A.J.P., Lamers, L.P.M., Lucassen, E.C.H.E.T., Vedle van der, G. \& Roelofs, J.G.M. 2006. Internal eutrophication: How it works and what to do about it - a review. Chemistry and Ecology 22: 93-111.

Turtola, E., Ekholm, P. \& Chardon, W. (eds.). 2010. Novel methods for reducing agricultural nutrient loading and eutrophication. MTT Science 10. 58 p.

Turtola, E. \& Jaakkola, A. 1986. Viljelykasvin, lannoituksen ja sadetuksen vaikutus kaliumin, kalsiumin, magnesiumin, natriumin, sulfaattirikin sekä kloridin huuhtoutumiseen savimaasta. (In Finnish). MTTK Tiedote 17/86. 43 p.

Uusitalo, R., Turtola, E., Grönroos, J., Kivistö, J., Mäntylahti, V., Turtola, A., Lemola, R. \& Salo, T. 2007. Finnish trends in phosphorus balances and soil test phosphorus. Agricultural and Food Science 16: 301-316. 
Uusitalo, R., Ylivainio, K., Hyväluoma, J., Rasa, K.,Kaseva, J., Nylund, P., Pietola, L. \& Turtola, E. 2012. The effects of gypsum on the transfer of phosphorus and other nutrients through clay soil monoliths Agricultural and Food Science 21: 260-278.

Valkama, E., Uusitalo, R. \& Turtola, E. 2011. Yield response models to phosphorus application: a research synthesis of Finnish field trials to optimize fertilizer P use of cereals. Nutrient Cycling in Agroecosystems 91: 1-15.

Valkama, P., Lahti, K. \& Särkelä, A. 2007a. Automaattinen veden laadun seuranta Lepsämänjoella. (In Finnish). Terra 119: 195-206.

Valkama, P., Lahti, K. \& Särkelä, A. 2007b. Fosforikuormituksen arviointi pelto-ojan valuma-alueelta ylivirtaama-aikoina. (In Finnish). Vesitalous 48: 30-34.

Valkama, P., Lahti, K. \& Särkelä, A. 2008. Fosfori- ja typpikuormituksen muodostuminen Lepsämänjoessa kevät ja syystulvatilanteissa. (In Finnish). Vesitalous 49: 26-30.

Watts, D.B. \& Torbert, H.A. 2009. Impact of gypsum applied to grass buffer strips on reducing soluble P in surface water runoff. Journal of Environmental Quality 38: 1511-1517.

Withers, P.J.A., Hodgkinson, R.A., Barberis, E., Presta, M., Hartikainen, H., Quinton, J., Miller, N., Sisak, I., Strauss, P. \& Mentler, A. 2007. An environmental soil test to estimate the intrinsic risk of sediment and phosphorus mobilization from European soils. Soil Use and Management 23: 57-70.

Vuorenmaa, J., Rekolainen, S., Lepistö, A., Kenttämies, K. \& Kauppila, P. 2002. Losses of nitrogen and phosphorus from agricultural and forest areas in Finland during the 1980s and 1990s. Environmental Monitoring and Assessment 76: 213-248.

Vuorinen, J. \& Mäkitie, O. 1955. The method of soil testing in use in Finland. Agrogeological Publications 63: 1-44.

YKR. 2011. The YKR database. Finnish Monitoring System of Urban Form and Spatial Structure. The Finnish Environment Institute and the Statistics Finland, Helsinki.

Yli-Halla, M. \& Hartikainen, H. 1996. Release of soil phosphorus during runoff as affected by ionic strength and temperature. Agricultural and Food Science in Finland 5: 193-202.

Yli-Halla, M., Pietola, L. \& Kauppila, R. 2011. Retrospect of sulphur fertilization in Finland. Proceedings of the 15th World Fertilizer Congress of the International Scientific Centre for Fertilizers (CIEC): 133-138.

Zhu, B. \& Alva, A.K. 1994. The effect of gypsum amendment on transport of phosphorus in a sandy soil. Water Air and Soil Pollution 78: 375-382. 